\title{
CYP2D6*36 Allele
}

National Cancer Institute

\section{Source}

National Cancer Institute. CYP2D6*36 Allele. NCI Thesaurus. Code C46055.

Human CYP2D6*36 allele is located in the vicinity of $22 \mathrm{q} 13.1$ and is approximately $4 \mathrm{~kb}$ in length. This allele, a variant form of the CYP2D6 wild-type allele, encodes cytochrome P450 2D6*36 protein. The CYP2D6*36 allele exhibits a clinically-relevant SNP (g.100C>T) that results in a P34S coding change. This alteration decreases the enzymatic activity of the cytochrome P450 2D6*36 protein. 